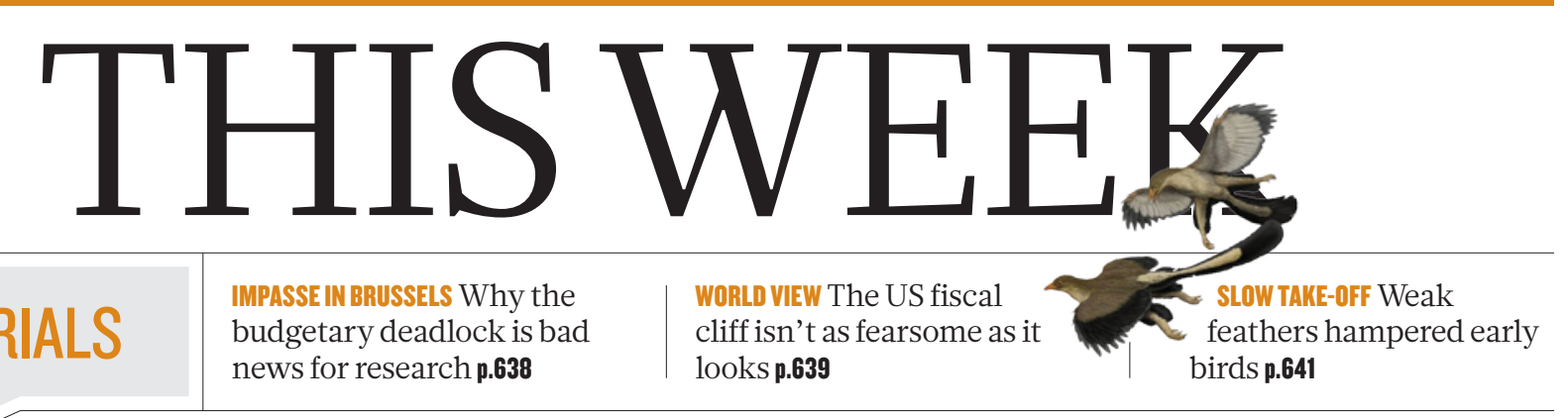

EDITORIALS

budgetary deadlock is bad news for research $p .638$ cliff isn't as fearsome as looks p.639 feathers hampered early

birds $\mathbf{p . 6 4 1}$

\title{
Misguided cancer goal
}

\author{
An influential US advocacy group has set a deadline to beat breast cancer by 2020. But it puts \\ public trust at risk by promising an objective that science cannot yet deliver.
}

$\mathrm{H}$ ope is not a good strategy, in life or in disease research. So the setting of goals, and the drive to reach them, is to be commended, and cancer is no exception. But a 2020 deadline for 'ending' breast cancer that former US President Bill Clinton endorsed earlier this month is misguided. Like other 'beat cancer' deadlines that are regularly floated, it is potentially harmful to the public trust that underpins the whole research enterprise, not to mention to the patients who understandably cling to hope, whatever its validity.

Clinton, who lost his mother to breast cancer, has become honorary chairman of a two-year-old campaign by the National Breast Cancer Coalition, which declares on its website that it has "One Mission: To End Breast Cancer by January 1, 2020". The advocacy and research-funding organization, based in Washington DC, adds that it has a "strategic plan" to achieve that mission, by focusing on prevention and on eliminating the metastatic form of the disease, which is what kills.

The coalition provides a 4.5-page "blueprint" that is long on aspiration and short on scientific detail. For instance, it declares that by 2020 "we must understand how to prevent people from getting breast cancer in the first place". This goal leans heavily on the development of a preventive breast-cancer vaccine. A research plan for this is said to be "in place" and will serve as a model for other, "catalytic projects". These could include exploiting the role of viruses and inflammation in breast cancer, and targeting the immune system to prevent metastasis.

Ambitious goals are perfectly defensible, and indeed desirable, when we have the means to achieve them. The campaign to eradicate smallpox made eminent sense once a vaccine was ready, as does the goal of eliminating polio. Yet the thorny problems of finishing off even polio, for which we have had a vaccine for nearly 60 years, provide a cautionary tale about the advisability of setting out to eliminate any disease.

This is particularly true of the myriad diseases we collectively call cancer, the complexities of which we have scarcely begun to fathom. Consider just one study, published earlier this year (P. J. Stephens et al. Nature 486, 400-404; 2012), which analysed protein-coding genes in breast cancers from 100 different women and found no fewer than 40 different mutational drivers of the disease. These were found in 73 different combinations in the 100 patients, who each had between one and six mutations. The low-hanging fruit here is scarce: only 28 of the patients harboured just one mutation, and finding a targeted therapy for even these single-mutation cases will be a daunting task.

Added to that is the disease's intractability. It cannot be banished like smallpox; our biologies are by definition vulnerable to a disease that has infinite manifestations profoundly rooted in our genetics. Even if a panoply of promising therapies were available, the eight to ten years it takes to complete a clinical trial makes a 2020 deadline impossible. As for prevention, truly valuable trials require not years but decades, because of the various influences on breast-cancer development during a lifetime. Britain's Breakthrough Generations Study, which recruited its 100,000 th participant in 2009, anticipates running for 40 years.
The National Breast Cancer Coalition counters that such arguments cater to those content with the status quo - what the coalition sees as the drift of a research enterprise that, after decades of investment, is not motivated by sufficient urgency. On the contrary: we are all for urgency, but in the service of goals that are within the realms of possibility.

Here are a few. Set out to identify all tumours in which the HER2 gene is mutated and treat them with the drug Herceptin (trastuzumab) by 2020. The treatment is known to work for this
"Discovery does not answer to deadlines." genetic category of the disease, so this is not inconceivable. Or declare that in five years, we will have developed several robust breast-cancer models that could rapidly be deployed to evaluate the functional significance of the mutations and polymorphisms that genomics is uncovering at a breathtaking rate. A project such as this, with finite parameters and price tag, can be pegged to an achievable time frame.

Or, tackle another cancer afflicting women by campaigning to overcome the apathy with which the human papillomavirus vaccine has been greeted in the United States. Universal vaccination of 11- and 12 -year-old girls against the cervical-cancer-causing virus would, at a stroke, provide huge gains against the roughly 4,000 deaths and 12,000 new cases of this cancer that are seen in the United States each year.

Discovery does not answer to deadlines, and campaigns that pretend that it does risk wasting public trust, whether from the taxpayers who support the US National Institutes of Health or from the millions of donors who give to dozens of disease-advocacy groups. There is a fine line between creating a sense of urgency and promising too much; it is best to stay on the side of the line that is realistic about how science works, and about what is currently achievable.

\section{A way to buy time}

With climate talks inching along, gains in energy efficiency could slow the rise in emissions.

$\mathrm{T}$ This week and next, diplomats from around the world gather once again to discuss global warming. With commitments under the Kyoto Protocol ending this year (see page 653), one key goal of the United Nations meeting in Doha is to make progress towards the 2015 signing of a new global climate treaty, to take effect by 2020 . The world is on track for a temperature increase of up to $4^{\circ} \mathrm{C}$ by the end of the century, but the UN hopes to limit that to just $2{ }^{\circ} \mathrm{C}$.

Unfortunately, diplomacy and global warming operate on incompatible schedules. An eight-year wait for action would seem to put the 
warming goal firmly out of reach. But there are ways to buy time for global diplomacy, and energy efficiency is at the top of the list.

The World Energy Outlook 2012 report from the International Energy Agency (IEA) suggests that the global infrastructure could lock in enough carbon emissions by 2017 to exceed the $2^{\circ} \mathrm{C}$ goal, unless facilities such as power plants, factories and buildings are expensively retrofitted or prematurely retired. But the IEA found that improving energy efficiency could give the world another five years to change course and begin the transition to renewables and other low-carbon energies.

Globally, energy use is projected to increase by more than one-third by 2035 , despite promises by Japan, Europe, China and the United States to curb demand. In an 'efficient world' scenario, with more countries embracing bigger efficiency goals, the projected energy demand could be cut by half. For perspective, the IEA estimates that the modest efficiency increases achieved between 1980 and 2010 reduced global energy demand by $35 \%$ - roughly equivalent to the energy currently consumed by China and the United States combined.

The IEA suggests that more-aggressive efficiency measures, such as a broad shift toward efficient appliances, vehicles, homes and factories, would cost an extra US\$11.8 trillion between now and 2035. But the pay-off would be substantial: direct fuel expenditures would fall by $\$ 17.5$ trillion, and investments in energy infrastructure by nearly $\$ 5.9$ trillion. Those savings would be reinvested elsewhere, helping to increase global economic output by some $\$ 18$ trillion. Unfortunately, the potential gains are dispersed throughout a complex marketplace that tends to reward short-term thinking.

Governments must pursue solutions at all levels, and not wait until the next global treaty. Reducing subsidies on fossil fuels would cut energy consumption, for instance, as would increasing consumption taxes. High energy taxes help to explain why Japan and Europe are leaders in energy efficiency, just as increasing oil prices on the global market have encouraged Americans to reduce their oil consumption.

But playing with the price won't work if the signals aren't reaching

"Improving energy efficiency could give the world another five years to change course." require energy audits when properties are sold; this encourages buyers and sellers alike to consider long-term operating costs.

In Doha and beyond, negotiators must look for opportunities for the world to embrace new and more ambitious climate goals. At the same time, governments must do everything they can to follow through with their own climate commitments, reduce carbon footprints at home and lay the groundwork for future steps. Stabilizing the climate will require monumental efforts on all fronts, and governments should recognize that money spent now on curbing greenhouse-gas emissions is a long-term investment that will pay off down the road. Nowhere is this clearer than in the arena of energy efficiency.

\section{A bleak Horizon}

\section{Researchers should lobby against heavy cuts to pan-European research funds.}

\section{A} fter much posturing and politicking, European leaders walked away from talks last week without a deal on the European budget for the rest of the decade. The breakdown casts into limbo a European Commission proposal to apportion around $€ 80$ billion (US $\$ 104$ billion) to research over the period 2014-20 - a $€ 29.5$ billion rise on Europe's current seventh Framework programme. And it augurs trouble for research when the impasse is finally broken.

With 27 nations each pushing for their own priorities, finding an agreement on spending plans is inevitably complex, and the tight economic climate aggravated the differences even more than usual.

The key divisive factor is the demand from wealthy nations, including the United Kingdom, Germany and the Netherlands, for substantial cuts to the total $€ 1.025$-trillion European Union (EU) budget - a rise of around $€ 50$ billion on spending between 2007 and 2013 - proposed by the European Commission. Early in the talks, European Council president Herman Van Rompuy, who is chairing the negotiations, proposed a cut of $€ 80$ billion. Media reports say that rich nations are looking for further cuts, of between $€ 30$ billion and $€ 75$ billion. Speaking to reporters after the talks broke down on Friday afternoon, Van Rompuy said that member states had found a "sufficient degree of potential convergence" to make an agreement on the budget possible early next year.

This should leave enough time for the European Parliament, member states and the commission to thrash out the final details of the research programme, known as Horizon 2020, just in time for research projects to start in 2014, as planned. But that is one of the few bright spots in the outlook for research.

Of the cuts suggested by Van Rompuy, the Horizon 2020 research programme comes out among the worst, with a proposed $12 \%$ reduction in funding, according to calculations by the Initiative for Science in Europe (ISE), an independent advocacy coalition of learned societies and scientific organizations in Heidelberg, Germany. The Galileo satellite network, set to rival the US Global Positioning system, faces a $10 \%$ cut, and the budget for ITER, the world's largest nuclear-fusion experiment, is also under threat. Van Rompuy says member states agree that the final budget should encourage economic growth, by focusing spending on research and innovation, as well as on jobs. But EU politics force other priorities. The sharp cuts for research in the Van Rompuy plans allow for more moderate reductions of $3.7 \%$ in the budget for agriculture to appease France, and of 5.6\% to 'cohesion funds' meant for poorer EU regions, to bring Poland on board with the negotiations.

If the proposed $12 \%$ cut to research funding sticks in the final deal, all aspects of the Horizon 2020 programme are likely to suffer equally. Unforgivably, this would include the programme's 'Excellent Science' initiatives, such as the European Research Council (ERC), which funds investigator-led frontier research, as well as research infrastructures, such as CERN - the world's largest particle-physics laboratory, near Geneva in Switzerland, and the institution responsible for the recent discovery of the Higgs boson. The valuable Marie Curie fellowships through which young researchers gain support for career development and experience working in labs abroad would also be threatened.

Helga Nowotny, president of the ERC, sees a bleak future for the council under the Van Rompuy proposals. She fears that the suggested cuts could result in funding for grants in 2014 dropping below levels available in 2009-10. Reductions of this magnitude will decimate success rates, particularly for young researchers, for whom other funding sources are scarce, she says. This would seriously damage the reputation painstakingly built by the ERC since it was founded just five years ago.

European researchers should do everything in their power to articulate the case for Europe's developing excellence, on which its future supply of scientific and technical manpower will depend. They $\rightarrow$ NATURE.COM To comment online, click on Editorials at: go.nature.com/xhunqv should lobby their national leaders and support the efforts of the ISE. They can start by signing the petition, which had, as Nature went to press, collected almost 149,000 signatures, at: go.nature.com/s2nm1w. 